\title{
LANDSCAPE WITH A WHINING SHINBONE: ON A LEGEND IN THE ESTONIAN FOLK TALE ANTHOLOGY BY FRIEDRICH REINHOLD KREUTZWALD
}

\author{
Mare Kalda
}

\begin{abstract}
The article is a diachronic analysis of a legend in the folk tale anthology by Friedrich Reinhold Kreutzwald, Eesti rahva ennemuistsed jutud ('Ancient Estonian Folk Tales', first edition published in 1866). The compiler of the anthology gave the tale the title "The Whining Shinbone" (in Estonian Vinguv jalaluu). The legend is about a corpse left behind in a valley after an ancient war, and which began to make itself known at nights as a whining bone, until some brave man gave it a proper burial and the dead soul eventually found peace. Almost as a reward, the man in question later came upon an enormous fortune. Intertextual analysis of all the times the legend has been textualised reveals the extent to which a published version of the legend has influenced (and still influences) the oral spread of the tale. The features of this influence can be observed while comparing the published texts and tales recorded from memory or oral lore.
\end{abstract}

Key words: intertextuality and intratextuality, legend textualisation, localisation of legend, published legend, the influence of published texts on oral tradition, thick and sparse text corpus

\section{THE AUTHOR OF EPICS AND ANCIENT TALES FROM THE "FOLK MOUTH"}

In 1866, the anthology of Estonian folk tales entitled Eestirahva ennemuistsed jutud ('Ancient Estonian Folk Tales') and compiled by Friedrich Reinhold Kreutzwald (1803-1882) was published by the Finnish Literary Society in Helsinki. This article is essentially a description of the fate of one legend included in the folk tale anthology, or more precisely, of how the legend of the whining shinbone has been repeatedly published in folk tale anthologies, also considering the instances of how the published legend has been retold in oral lore and the different instances of how an independent variant of the legend has been retextualised in oral lore. 
Before focusing on the aforementioned subject, the article will provide an overview of the book's cultural context and the compiler's biographical background and how it relates to the intentions of the compiler.

In the first decades of the 19th century, Kreutzwald was among the few Estonians who had received a fairly decent education and had entered a higher social circle than that of his peers. This enabled him to establish contacts with the local Balto-German circles. Such upstarts generally adopted German as their home language and married German women. Kreutzwald came from a family of manor servants but had passed through all the levels of education available at the time, had studied medicine and ran a medical practice in town until quite an advanced age. ${ }^{1} \mathrm{He}$ took an interest in folklore and literature throughout his life, was familiar with the cultural life of Western Europe, and was clearly influenced by the intellectual movements of this culture area, especially the pre-Romantic Sturm und Drang movement, including the folklore activities of Johann Gottfried Herder towards the end of the 18th century (Talvet 2003; Tohver 1932). He was also familiar with the song tradition and narratives of the countryfolk and concluded that the Estonians actually had their own grand epic which, though existing in fragments, needed to be collected piece by piece and compiled into a book. Inspired by the publication of the Kalevala epic in 1836 in Finland, Kreutzwald was convinced that if other peoples had a national epic, the Estonians could also have an epic of their own.

Alongside his professional career, he went on to achieve his goal and become the author of the Estonian national epic Kalevipoeg. The Estonian Learned Society first published this book as an academic publication in its Proceedings (1857-1861). For the general Estonian public, the book was published in 1862 in Kuopio by Finnish scholars who shared his ideas. Kalevipoeg as a national symbol exerted significant influence on the Estonian national movement in the second half of the 19th century, the epic becoming a cultural source text. ${ }^{2}$ This has given the Estonians the reason to consider Kreutzwald the founder of Estonian literature and among the first folklorists in Estonia. ${ }^{3}$

With nearly as much zeal as he had for compiling the epic, Kreutzwald started to work at publishing Estonian folk tales. In his work he attempted to apply the strategy which had been effective in his work at editing the epic. The strategy involved the composition of a complete epic from the collected fragmentary pieces of oral lore (further on the strategy see Annist 2005, Valk 2002). Regardless of various problems, such as the loss of a part of the manuscript, Kreutzwald's work led to publishing the book in Finland.

When engaged in the poetisation of the epic, Kreutzwald had felt like an author, but in the case of the narrative anthology he emphasised the "folkness" or folkloric authenticity of the texts. This idea is immediately expressed in his 
statement on the title page under the book's title: "Rahva suust korjanud ja üles kirjutanud Friedrich Reinhold Kreutzwald" ('Written and recorded from people by Friedrich Reinhold Kreutzwald') (see Kreutzwald 1866 and reprints in Estonian ${ }^{4}$ ). Indications that Kreutzwald's understanding of the need to publish the tales in their original, popular form was a conscious choice from early on can be found in his earlier writings. For example, after certain Estonian folk tales had been published in the Baltic-German weekly Das Inland, Kreutzwald harshly criticised their distance from authentic folk tales. He published his variant of the example that he found most upsetting under the title Der dankbare Fürstensohn, in the preface of which he writes,

Wer Estnische Volksmährchen mittheilen will, muß sie so geben, wie sie im Munde des Volkes leben, nicht aus bruchstücklichen Notizen, wie man sie etwa in den Papieren eines Verstorbenen vorgefunden (Kreutzwald 1850: 75).

Without meaning to lapse into the details of this minor textual conflict any further, ${ }^{5}$ it should be noted that in the same piece of writing he criticised the folk tale adaptations of some earlier German authors, the style of which he did not consider proper for Estonian translations,

Die gewandte Feder eines Musäus oder Hauff hätte aus diesem Mährchen eine angenehme Lectüre geschaffen, aber da wäre es kein Estnisches geblieben. Die deutsche Literatur hat der Unterhaltungsschriften die Fülle, sie braucht keinen neuen Zuwachs aus der Estnischen (Kreutzwald 1850: 75).

Kreutzwald often contemplated on folk tales in his personal letters to his friends and people who shared his thoughts. For example, a year after the anthology was published, he assured Georg Schultz-Bertram (1808-1875), a doctor, politician and writer interested in the antiquities, that the tales included in the anthology were recorded verbatim from narrators. He even denied borrowing certain features in his letter to Schultz-Bertram,

"Eestirahva ennemuistsed jutud", welche in der Helsingforsischer Ausgabe veröffentlicht worden sind, stammen von A-Z aus dem Munde des Estenvolkes, und zwar der Mehrzahl nach sind sie fast wörtlich so niedergeschrieben, wie sie von den jedesmaligen Erzählern mitgetheilt wurden. Es lag mir besonders viel daran, keine Eigenthümlichkeit zu verwischen, denn gerade die Art und Weise, wie jedes Volk seine Märchenstoffe bearbeitet, ist von grossem Interesse (In his letter to G. Schultz-Bertram on February 17, 1867; Kreutzwald 1959: 185; the 
original in German held in the Estonian Cultural History Archives, EÕS, M.A. 169: 23).

Certainly, his arguments are not all solid, since similar sentiments and style were highly typical of the Romantic folk tale anthologies of the period. Whatever the case, the folk tales (and legends) published in the collection started to shape the views of the general public towards the Estonian folk tale. The format of the printed legend then started to influence the textualisation of the tale in different performance situations, in both oral and written form.

The publishing of the folk tale anthology marks the beginning of developing narratological terminology in Estonian. Kreutzwald distinguishes between two folk tale genres - Märchen (in Estonian ennemuistsed jutud, lit. 'ancient folk tales') and Localsagen (in Estonian paiklikud ennemuistsed jutud, lit. 'local folk tales': see also Jaago 2005: 32). ${ }^{6}$

\section{THE MÄRCHEN ANTHOLOGY AND NEW EDITIONS}

The legend can first of all be analysed from a bibliographical point of view. The publication of the legend in new editions of the anthology gives some idea of when the same text was updated in the local cultural context. Nevertheless, in the peaceful course of the nation's socio-political development, the books that have already been published are also preserved as cultural resources. The number of available written texts is increasing, and this is having a clear impact on the later oral reproductions, which are partly reflected in recorded folklore materials. ${ }^{7}$ Apparently, it cannot be taken for granted that tales that have been published in different editions are the same variants. Like an oral narrative, which is introduced in a new context each time it is retold, a legend anthology emerges in a new context and its contextual elements - such as the book's design, illustrations, and the expectations and interests of its readers have changed.

The new editions of the anthology Eestirahva ennemuistsed jutud were by no means identical, and the same applies to the legend of "The Whining Shinbone".

The following are the most significant dates in the history of the publication of the legend:

1866: the legend is published among 43 Märchen and 18 Localsagen (Kreutzwald 1866);

1875 and 1901: the 2nd and 3rd edition of the book in Estonian are published in unaltered form; 
Figure 1. The first edition of Kreutzwald's Eestirahva ennemuistsed jutud was published in 1866 in Helsinki.

1881: the second volume of the German translation of the anthology is published. The publication includes 18 legends, among which the legend under discussion is entitled Der winselnde Fußknöchel; 8

1924 and 1951: only (a selection of) Märchen, but no legends, were published in an anthology under the same title;

1953: the 6th edition of the anthology was published in the Estonian language, including eight of the original 18 Localsagen;

1967, 1978 and 1996: the complete edition was published (the 9 th edition is a reprint of the 1967 publication);

2003: an Estonian publishing house published a separate book of eight tales from the Localsagen volume of the anthology under the title of the anthology's final subsection, Paiklikud ennemuistsed jutud ('Localsagen' Kreutzwald 2003).

All of the editions in which Localsagen were represented include the tale of "The Whining Shinbone."

\section{LOCALSAGEN IN THE AREA OF INTER- AND INTRATEXTUAL RESEARCH}

The history of the publication of the legend under investigation is important because published texts and recorded oral versions in the folklore archives represent the specific instances in which a legend has been textualised. The documented cases of textualisation become fixed points that represent the intertextual chain of the legend of "The Whining Shinbone" over time. In the following the legend as a setting in a physical landscape and the way in which the physical landscape has been represented in the text will be discussed. The strategies of textualisation employed by Kreutzwald pose some questions. Ülo Valk emphasises the role of Kreutzwald as the person who wrote the epic Kalevipoeg, that Kreutzwald as the author dominated the text while creating the epic (Valk 2002: 409). If this is the case, then is the author's voice also dominant over the Localsagen? In other words, can a reader encounter the 
narrator of the epic, as it is said in the legend "in a narrow valley, where people have often heard a sorrowful whining, which sounded like an animal suffering torture"? Is this a case of the author creating a legendary landscape, or has he merely described the physical surroundings? My answer would be no - here the tale has not been told from the same authorial position as that which Ülo Valk has argued with regard to Kalevipoeg. Here it is once again worth remembering that Kreutzwald emphasised the folkish nature of the tales. If, indeed, he shaped the epic publication to be as folkloric as possible, the localisation of the published legend may be considered authentic.

If the compiler does not assume the role of author and - as it turned out even denies his authorship, then who and what shaped the textuality of Localsagen, and the wording of these spatial relations in narratives? Textuality is formed by the same components that Ülo Valk listed as the constituents of an epic: an author (who in this case functions as the narrator of the tales), a performance and a landscape (Valk 1992: 414-418). In terms of folklore, oral narration, the variants of the same narrative heard (or read) by the narrator have to be considered together with the factors that shape textuality - that is, the aspect of intertextuality has to be taken into consideration. Here arises the issue of the status or authority of the mediated text. Together with the circumstances of the performance context, the authority of the text impels the narrator to either change the narrated text or retain its original form. If the narrator acknowledges the authority of the variant of the tale that he or she has heard before, the verbalisation will be, very likely, more or less identical with the previously heard tale. Then again, the narrator might formulate a competing variant which invalidates the authority of the former variant. This also affects the textualisation of the text in a new performance. A text that passes on (authoritative) information about something cannot be a passive body of words fitted in the performance situation - instead, its emergence is in some ways inevitable, it has been called forth either in oral (conversation, speech, rhetoric) or written form (a publication, a folkloric contribution to the archives, a letter to a friend). A book legend shows potential to have an authoritative effect.

Texts that keep re-emerging in a cultural context enter into intertextual relationships with one another. In an attempt to describe the chains formed by the different recorded variants of the legend of "The Whining Shinbone", I will first point out the main principles of intertextuality. Intertextual analysis is most common in the studying of fiction, but since intertextual relations serve as the precondition for the entire communication, the phenomenon is generally inherent in all culture (Makkonen 1991: 19). 
Although intertextuality has been a favourite topic of studies in literary theory since the 1960s, some authors have noticed that the topic has been much more extensively discussed in folklore studies. ${ }^{9}$ Richard Bauman (2004: 1-2) shows that the discovery of intertextual relationships leads to philological textual criticism as the scholarly tradition of folklore studies (and anthropology) already in the works of Johann Gottfried Herder, the Grimm brothers and Franz Boas. The Finnish literary historian Kai Laitinen was surprised to discover that theoreticians of intertextuality had largely overlooked earlier studies by folklorists, and pointed to the History of Finnish Literature (1885), in which Julius Krohn had formulated the main principles of borrowing and influences (Laitinen 1995: 141-142). The concept of intertextuality was developed by Julia Kristeva, who was inspired by the Bakhtinian concept of dialogism. Bakhtin pointed to the continuous dialogue of ideas, words, texts, and styles with other ideas, words, texts and styles (see, for example, Bakhtin 1996). Kristeva (1980: 66) characterised texts from the aspect of intertextuality as a mosaic of quotations, in which each text draws in other texts and transforms them. The present study, however, focuses on intratextuality, a narrower and more limited field of intertextuality, since it explores the relations between the recurrent emergences of what is basically the same text, to which folklore collectors or narrators have either added or removed textual units. Conducting a folkloristic comparison of the written variants of the legend of "The Whining Shinbone", there arises the question of the degree to which the legend(s) by Kreutzwald become the source text(s) of the texts surrounding them in the archives and in possible oral discourse.

The principle episodes of the plot of the book legend are the following:

- "A sorrowful whining noise" is heard while a person is walking from Aruküla village towards Kadrina church in Jõepere village.

- A brave young man from Aruküla village finds a bone and picks it up.

- The bone transforms into a strange man - a Swedish nobleman who asks to be given a burial service.

- The young man summons a minister and grants the dead man's wish.

- The man finds a copper pot 'filled to the brim with Swedish thalers' [einen Kessel, der bis an den Rand mit schwedischen Thalern angefüllt war].

- The finder of the money pot leaves his home as a rich man and 'after that no man has heard the whining of the shinbone in the valley' [Nach dieser Zeit hat keines Menschen Ohr mehr in der Schlucht das Winseln des Fußknöchels gehört]. 


\section{THE CONTENTS AND DENSITY OF THE TEXT CORPUS}

The corpus of the legends is constituted of printed texts (eight new editions within 137 years) and the recordings of the tales in the Estonian Folklore Archives (transcriptions of oral legends made at different times and held in the Estonian Folklore Archives). The published "variants" are similar but they have become topical in culture at different periods. The experience of readers of any new edition very likely differes from the reading experience of previous readers. In the context of literary culture, reading legends from a book is quite common. Some legends in Kreutzwald's anthology have been included in the reading lists of courses in Estonian literature and the print number is higher because in addition to re-editions of the anthology, it has been published in various editions of school readers. ${ }^{10}$ As a result, the number of people familiar with the story (in Estonia) is quite remarkable and thus allows intertextual allusions to the familiar text in various new contexts. This does not particularly apply to the tale of "The Whining Shinbone" which has inspired few allusions but is true of the legends "Die Tochter des Strandbewohners von Tolsburg" ('Daughter of the Coastal Man of Tolsburg'), "Das Fräulein von Borkholm" ('The Mistress of Borkholm') or "Das Mädchen von Waskjalasild" ('The Maiden from Vaskjalasild') ${ }^{11}$ and most importantly, in terms of the plot most symbolical for Tallinn, the capital of Estonia, "Warum Reval niemals fertig werden darf" ('Why Can't Tallinn Ever Be Finished?'). Learning about oral narrative lore is a unique and at the same time as important link in the migratory chain of folklore as oral transmission in "natural" narrative situation or publication in the press. True, if we presume that the reception of an oral legend differs from the reception of a published (author's) legend, then reading a legend in a textbook and discussing it in classroom opens the channel for adopting the published legend. In this case, the mental text is not constructed or "saved" for potential new performances, which would be otherwise anticipated in terms of a fully oral distribution chain (on mental text see Honko 2000: 18-19). Folklore collections suggest, and in more instances than the couple of texts from Kreutzwald's collection, that the published legend has, in fact, entered the oral repertoire. The course of events in the described manner is intertextually anticipatory and functional, although condemned in terms of authenticity because the published legends and tales which are passed on orally get mixed in this way.

The narrative context of "The Whining Shinbone" as a local legend from Aruküla is the plot of a whining human bone known all over the country (in Aarne's legend type register Aa S 12: der Knochen schreit: Als er von Neuem begraben wird, verstummt er; Aarne 1918), which became localised in different 
places. The popularity of the legend confirms the authenticity or folkness of the Kreutzwald's text. In different variants, the episodes vary - for instance, in tale type Aa S12 the plot usually concludes with a traditional burial of the bone, whereas the episode of funerals is rather laconic; in the composition of the legend in the anthology, the dialogue between the man from Aruküla (observer of the bone) and the personalised corpse, the funeral ceremony as well as finding the fortune (the latter aspect is generally missing in tale type Aa S 12) form the main part of the legend.

At the beginning of the text corpus and the intertextual chain there is a hypothetical source text, the legend that Kreutzwald had heard in his childhood (Annist 1966: 237). This, of course, does not mean that this is the very first text of the whining shinbone discourse. This was a performance situation of the text (or repeated performances) which the hearer remembered and may have reproduced later (perhaps in written form) as a new narrator. Scholars studying the life and work of Kreutzwald have unanimously presented information as to how the future writer visited places that have been mentioned in legends associated with Kalevipoeg at the age of ten, such as Kalevipoeg's hills, his horse's "footprints", or the furrows he "ploughed", as legends have it, and how in the mind of the observer the legends told by the manor servant Kotlep (see Suits 1984: 12-13; Annist 1987: 128; on visiting legend places in general, e.g. Valk 2002: 415-416) were related to specific places. The setting of this legend, however, is at the very site, where Kalevipoeg, the Estonian giant hero had shaped the landscape and inspired folk tales.

Variant 1 is Kreutzwald's reply to Anton Schiefner ${ }^{12}$ in a private letter written on March 10, 1862. Schiefner, who helped Kreutzwald in publishing both the epic and the folktale anthology, was living in St Petersburg at the time and had asked whether the folktale of a grateful dead who saves his helper from danger in return of a funeral service and makes him a rich man was known in Estonia. In his reply, Kreutzwald copied his pre-publication variant of the legend, according to which a brave man finds a howling shinbone in the bottom of the valley near Aruküla village. The bone asks to be blessed and buried, but unlike the later variant which is published in the anthology, the bone does not assume the shape of a human being for giving these instructions. Then the man takes the bone to church to be blessed (a unique detail which is not included in any other variant or the published legend), and later, while digging a grave for the bone, comes upon a tremendous fortune. Nobody has heard the bone howling since it has been buried (Kreutzwald 1953: 235236; 238; the German original held in Estonian Cultural History Archives, F 64, M 3: 1). In the legend variant sent in the form of private correspondence to Schiefner, some narrative events have been told in the present tense and 
the text differs from the variant published in the anthology, though the textualiser is the same. ${ }^{13}$

Variant 2. In 1888, Ernst Hannov from Tapa contributed to the folklore collection launched by Jakob Hurt a legend entitled "The Living Shinbone" (original title Elav sääreluu, H II 14, 543/5 (1)) and framed the lengthy tale, quite similar to those recorded by Kreutzwald, with the following sentence: "I heard the following tale in childhood, in Tartu from Anne Koppel, who lived in Roela parish near Laius-Tähkvere."

The variant is not included in the chain of intertextual relations owing to the spatial setting of events, but with its style and composition of episodes; thus, all textualisation devices other than the spatial settings are similar. As in Kreutzwald, Hannov's legend entails a longer dialogue between the man and the unhappy dead (although the bone does not turn into a warrior as in the legend in the anthology and the traveller is speaking to the talking bone as in Variant 1), a detailed description of the funeral and the fortune bestowed upon the man who organised the burial. Hannov mediated the legend which he claimed having heard in Tartu in his childhood.

In 1897, the legend was published in a German collection Livländisches Sagenbuch (Bienemann 1897, no 221) together with 22 treasure legends and with a reference to the first edition of Kreutzwald's anthology. It is unlikely that the local reader was influenced by Friedrich Bienemann junior's collection.

Variant 3. The text recorded by Alfred Kivi and entitled "Kindrali sä̈̈reluu" ('General's Shinbone'; E 34351 < Kadrina, Aaspere parish, Hõbeda village) also dates back to 1897. In this tale, the exact location of the shinbone is not mentioned (the whining was heard on the way to the church from a distant forest). Like in Kreutzwald's anthology, the shinbone transforms into a general, who in a long dialogue guides the finder to the place where the fortune is buried. But instead of the following lengthy passages, this tale presents laconic sentences about finding the money pot and the stopping of whining.

Variant 4. In 1902, folklore collector Aleksander Treumann recorded another variant of the legend (H III 30, 83/4 < Rakvere parish). In his account, which is full of orthographic mistakes, he tells about the same shinbone that is referred to in Kreutzwald's ancient tales but also constructs the narration as a legend of the origin of locality - the round valley called Säärevere Hole (sä̈r r, the first element of this compound name, means 'shin', 'leg' in Estonian) together with historical lore about the wartime shelter:

[...] There is a small rectangular pit and a bush near its bank, under which the shinbone stood and howled. An old man told that inside the hill there used to be a large cave where people found shelter in wartime. 
But the enemies had found out about it and suddenly appeared there, and there was bloodshed and pillage. Those hiding in the cave were all killed without mercy. Blood flowed up to the level of half leg. [...] But one shinbone was left lying outside under a bush; it whined and howled and emitted bloody foam for a long time after that so that the place came to be called Säärevere.

The legend diverges from Kreutzwald's variant both in contents and style, although it points to the relation by spatial setting.

Variant 5 is recorded in the neighbouring parish from Kaarel Metson, then 65 years old, by Linda Kuusler (Estonian Folklore Archives II 32, 425 (5) < Väike-Maarja parish < Viru-Jaagupi parish (1930)):

A young Swedish emperor was buried in Aruküla village. The whining bone was lying there on the ground. A man took the bone and the young emperor stood up in front of him. Then the emperor told him about all the gold under the ground and asked the man to be buried in the church. He told him, "Take the entire fortune from the ground!" The man did as he was told.

Variant 6 was recorded during a fieldwork expedition of the Estonian Literary Museum in Rakvere in 1984 . The legend was brilliantly narrated by an $80-$ year-old woman: ${ }^{14}$

But I will tell you a legend from the Swedish period. [...] I heard it from a Männilo, who is long dead by now [...], has been dead for a few decades or moh-rr over thirty years or forty. [...] This was the tale spoken during the Swedish time. [...] People were then robbed at home and [...] he had buried his treasures somewhere and then he was killed himself. When people went from Jõepere to - err - Aruküla village, then each time they went up there, ow-ow! and moaning, whenever there was moonlight. There was this howling. O-o-o-o ow-ow-ow-ow there was this man from Aruküla village. He was such a brave man and went to look, while other people wouldn't dare. [...] And he found there that there was this one bone, one human bone on the ground - I don't remember which bone it was - a shinbone or a calf bone. [...] And he then heard a man's voice which told him, "Dig here!" And so he did. He had a spade with him and all. He had the spade because he was digging this ditch in Jõepere, which - err - the ditch is still there, the one he dug. And he said that since you were such a brave person, that you came here. Then you know. Under this huge stone, which is [changing intonation:] guided to the hillock [with previous intonation] and a little further up to the hillock there is still a spring. And beneath the spring there lies the fortune. 
[Follows a long episode of describing how to summon the minister and how to dig up the treasure later]

[...] Beneath there is an iron chest and the treasure is in the iron chest, and I no longer remember how much of it there was. You will have to give some to the church and that much to the minister and whatever is left will be yours.

The man from Aruküla did so. Went to fetch the minister, but how about the minister. The minister [said] that no, child, you are about to commit a sin. [...]

[Episode describing the persuasion of the minister]

And came. Read the burial service and was shaking with fear and still put on his ro-robe or the minister's gown, and a [made] cross sign before him. And read and [...].

[About sending the minister back home]

Yes, and he went to dig it up. Dug and scooped and it took him great efforts before he managed to remove the stone. [...] But he found quite a large fortune. And, all in money. It was there, all in gold coins. From there he gave some to the minister, and then he gave some to the poor. But he took a large sum to himself. [...]

[The story how he told his wife about it]

But the woman had a good friend. So she told her. That, look, we are rich now my, husband, this way, got much gold money and very many valuables and. [...] The friend had also two friends. So the news already spread in the Aruküla village, the entire Aruküla. [...]

[The family left the village because of the gossip]

And he left and took the fortune along and has not returned to Aruküla since. This was the legend. (RKM, Mgn. II 3841 (9) < Rakvere l < ViruJaagupi parish, Inju village - E. Tampere, A. Urbel < Linda Nõlvandi, 80 yrs [1984])

Variant 7 is presented on a website introducing local tourist attractions (see http://www.eestigiid.ee), not so much in the form of a legend but as a reference to the legend:

Aruküla village ${ }^{\mathbf{1 5}}$ is situated at the Jõepere-Saksi road, in Vinni parish, West Viru County. According to the national census in 2000, the popula- 
tion of the village is 99. Aruküla village is associated with several legends about Kalevipoeg. Here is the bed of Kalevipoeg, his horse's skin bed and footprints, a bog emerged from the intestines of his horse, as legend has it. F. R. Kreutzwald published the legend of the whining shinbone of Aruküla, which, according to the legend, belonged to the Swedish king. There is a round valley connected with the same legend, called the Säärevere Hole near the village.

In terms of intertextual relations, the function of indicating to the legend in some context is quite telling - namely, "in some situations a reference represents or replaces the full text of the legend, for example, in case the audience knows the text referred to" (Ellis 1989: 35-36). Bill Ellis also indicates to presenting a legend in an abbreviated form, which may attest to the abandonment of the legend from active use or its variance from the new context.

A legend corpus represented by twenty or so texts is by no means perfect, without voids, dense, coherent - nothing like what Lauri Honko (2000: 26) considered crucial for obtaining accurate research results, although he considered it necessary for an accurate analysis of variation and meaning. Combinations of elements or the absence of them in a fragmentary sparse text corpus and the specific textualisation models achieved on the basis of these relations can, in fact, be studied, or to put it differently - it is possible to indicate how the source text has been actualised in a new or later performance or publication situation. Here the context of the chain links is formed of certain principles which join the topic: territorial principle (reader/narrator/listener can localise the tale and relate to the place of events), informative principle (reader/ narrator/listener are aware of the lore piece ${ }^{\mathbf{1 6}}$ ), and the principle of identifying with a group (the features defining the group in this case might be being familiar with the similar lore piece and/or Kreutzwald's anthology, folklore collection, even perhaps interest towards such legend texts). The seeming gaps in text corpus (intertextual silence) may convey the same meaning than pauses in a musical piece.

\section{WAYS OF TEXTUALISATION IN VARIANTS OF THE LEGEND "THE WHINING SHINBONE"}

While analysing the origin and artistic style of Kreutzwald's folk tales, August Annist explained how Kreutzwald approached the legend:

Most likely Kreutzwald was familiar with the story about the place where he grew up with since boyhood. In the mid-1860s, while revising the 
memorised legend for his anthology, he reconstructed the legend's contents and merged it with historical-ideological interpretation (Annist 1966: 237).

Both study of and the article on the source text form an intertextual relationship, the discourse of "The Whining Shinbone" legend. Discussing the genesis of the legend, Annist argued that Kreutzwald must have incorporated into the legend about the howling shinbone the special motif of a treasure - the leaving of the man who found the treasure from his former home place after he became wealthy. He also pointed out the difference between the published legend and the oral legend that Kreutzwald had forwarded to Schiefner in his letter. In other words, in the book legend the bone is described as an active character on many occasions: it did not only howl at nights but it entered a dialogue with the passerby and gave him detailed instructions as to what to do next. The written variant, however, does not contain the episode of sharing instructions, as the treasure is stumbled upon in the course of the bone's burial ceremony, even though there is no doubt that it was intended as a reward for his efforts. In his letter to a fellow thinker, Kreutzwald mentions nothing of the treasurefinder's travel to Finland or Sweden. Here it is worth agreeing with Annist's argument that Kreutzwald sent Schiefner a more authentic variant than the legend published later in the folktale collection (Annist 1966: 236). Evidently, Kreutzwald is the author of the entire episode of the bone's assuming a body, instead of identifying the warrior who emerged from who knows where as the king.

Like the published legend, the text recorded by Hannov in 1888 (Variant 2) and also the one recorded in 1984, which is the most masterful variant, are characterised by long-winded passages of texts. In Variant 2, the speaking bone (without assuming human shape!) instructs in great detail how to find inside the hillock the iron chest with gold and silver coins, some of which have to be given to the minister, some to the parish poor, while a quarter can be kept. Exactly the same takes place in the version in Localsagen and in the 1984 variant, although in these variants the bone undergoes a metamorphosis into a human being. The very laconic text recorded in 1930 mentions the bone's transformation into a young emperor, and gives information about the amount of the gold as well as the permission to keep the entire fortune. However, the legend explaining how Säärevere got its name, recorded in 1902, does not include the motif of finding the fortune. Folklore collector Kivi, however, structured the narration in such a way that he made the shinbone transform into a general who told a story about the wartime and guided the man to the digging site but never mentioned what the digger would find there. 
In most variants it is known that after regular burial ceremony, the dead person found its peace (and the man who buried it, got the money). But neither text by Kreutzwald or the majority of archive legends present Hannov's exemplary solution, according to which the entire community came to bury the bone and the man who buried it turned into someone who thanked God and admonished the community to sanctity. Interestingly, the conclusion arrived by Annist according to whom the motif of the exceptionally restless spirit of the deceased was added the motif of the peaceful effect of a Christian burial supports this emphasis.

In conclusion, the structure and order of episodes is generally the same in the published legend and archive texts, although the contents of episodes vary to a considerable degree.

\section{MODEL OF INTERTEXTUAL RELATIONS OF LEGEND VARIANTS ON THE TEMPORAL AXIS}

Estonian literary theorist Marin Laak and her research team developed an "hourglass model" for demonstrating and analysing the intertextual relations in the Estonian national epic Kalevipoeg (Laak 2003; Laak \& Viires 2004). ${ }^{17}$ The reason why the hourglass model cannot be applied here is that the chain of the research objects remains intratextual and the texts constructed on the basis of the source text are not entirely new (the only exceptions here are perhaps the introduction of the place on the tourist website, and as references to Annist's study suggest, also external texts about the legend), and the former text is only reformulated.

To demonstrate the relations graphically, the example texts are shown on a temporal axis and the relations between them pointed out. Some of these are speculative, only suggesting a possible relation. The materialisation of a possible relation, however, cannot be ruled out thus justifying the inclusion of also hypothetical chains next to documented links.

The first line of relations is formed of the published legend (incl. new editions of the anthology), the oral legend and the written variant in the letter by Kreutzwald to Schiefner (Variant 1) as its source texts. The latter dates the earliest variant to 1862 , but since Kreutzwald claims to have introduced the legend in active circulation, the source text can be placed on the temporal axis to a time before the anthology was published and before Kreutzwald's letter to Schiefner. The existence of a written recording of even earlier legend variant preceding the anthology cannot be ruled out. 


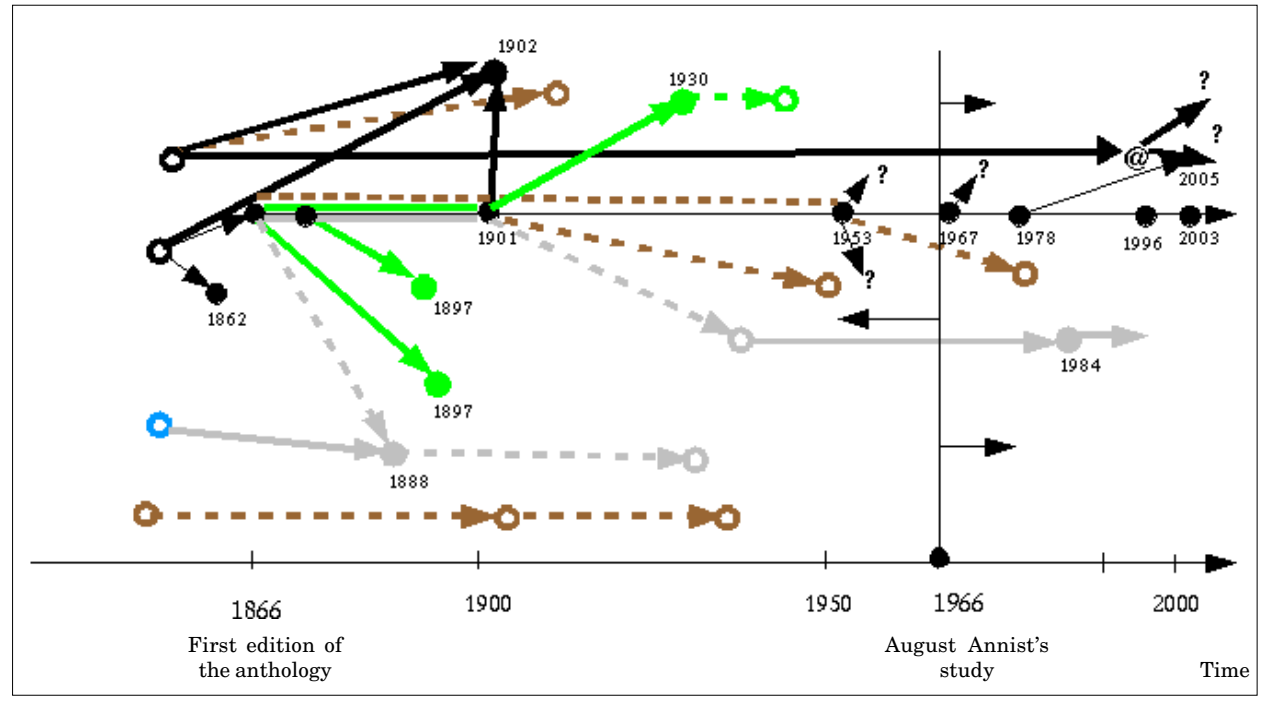

Figure 2. Model of intertextual relations of legend variants

Symbols

- Legend published in the collection Eesti rahva ennemuistsed jutud, in archives or a personal letter

O Speculated performance of the legend

$\rightarrow$ Established relation (effect)

$\rightarrow$ Speculated/hypothetical relation

? marks the relations questions posed about which cannot or are difficult to be answered on the basis of the available data.

First type of relations: black continuous line

Second type of relations: dark grey continuous line

Third type of relations: light grey continuous line

Fourth type of relations: bold black line

Fifth type of relations: dark grey broken line

Metatexts or texts about texts: vertical line

@ data available on the web

Relying on oral lore, Kreutzwald constructed a piece that was published as the 4th text in the Localsagen (see Kreutzwald 1881: 155-158). If the manuscript of the anthology was indeed completed by 1862, the legend forwarded to Schiefner in a private letter no longer could have influenced the legend text constructed for the anthology, but will become an example of a different performance of the legend by the same narrator (Kreutzwald) in a different performance situation.

The new editions of the legend expand the first relation line marking the line of an active spread of the printed variant in time. At certain points of time, the texts were reprinted over and over again and the published legend inevitably turned into a "source" or "keeper" of a tale in active repertoire for possible transmitters. No matter which new edition was used by the transmitter of the 
legend, the influence of the first edition extends to it by mediation of how Kreutzwald textualised it.

The second line of relations is formed of texts which clearly have a direct link to the published legend, such as the tale included in the 1897 Germanlanguage legend collection by Bienemann (at the end of the legend text Bienemann includes bibliographical information which traces the origin of the text back to the first edition of Kreutzwald's legend anthology), but also Kivi's account from 1897 (Variant 3; here we cannot rule out the knowledge of the tradition independent of the publications), and, possibly, also the laconic piece by Kaarel Metson from 1930.

A contextual element emerging in the second line of relations is the question of narrator's intentions. Historian Bienemann has compiled a selection of Livonian legends for a German-speaking audience, whereas Kivi recorded the tale for the purpose of collecting folklore.

While observing the single ways of textualisation, I have neglected to point out that Kivi made no reference to the spatial setting of the legend, but in the context of relations, this fact becomes quite important. The then 14-year-old, though a completely reliable folklore collector, may not have had a personal experience with the Aruküla region. Of course, this speculation might not be the reason why Kivi referred to the location of the legend's events with general expressions, such as "on the way to the church", stating that the voice was heard "from the distant forest". Still, the way the legend events have been localised requires the drawer of the lines of relations to have been flexible and consider various alternatives existing at the same time. Thus, the informant may have rephrased the published legend with an indetermined spatial setting, but he may have also heard somebody's recounting of the tale and written down the legend using the same wording than the previous narrator.

If this is the case, a third line of relations (marked on the graph in light grey) would be introduced: here the archive text is preceded by an oral narration, even though it is based on the anthology and is traceable back to it. This applies to the variants constructed by Hannov (1888) and Nõlvandi (1984). Of course, these are the same as those published in the anthology, but both emphasise a former source informant who, in turn, had read the legend and then passed it on, or had heard it in oral performance first (that is from someone who had read the legend in the collection).

Both lines of relation appear to be parallel with regard to the publication. It is difficult to determine whether Variants 2 and 6 could introduce an additional direct link to an independent elaboration of the legend. Possibly, the seemingly independent contents of these legends are merely different ways of textualisation by informant Hannov and narrator Nõlvandi. Also, it is not known 
whether their text influenced other narrators. The position of the legend documented in two different periods in the model is analogous. The analogy is rendered more complicated by the fact that the legend described by Hannov takes place somewhere else, although the structure of the tale and the construction of episodes are identical with the Aruküla legend of "The Whining Shinbone".

Treumann's account from 1902 (Variant 4) opens with the following sentences, "Säärevere is located in Neeruti, Kadrina parish. There is a hill called Ämmamägi [lit. 'Hill of Mother-in-Law']. This is where the shinbone was lying, as Kreutzwald's ancient tales have it."

Consequently, the tale is in referential relation with Kreutzwald's anthology, although the published legend is not reproduced and a completely new elaboration of the tale is presented. The line of relations (4th line of relations; bold black line on the graph) traces this variant back to some former piece of oral lore, which was not based on the anthology. Treumann, the informant of this tale, consciously avoided the mixing or joining of plots. An interesting leap in time is represented by the situation in which the laconic introduction of a location on the tourist website (Variant 7) summarises this very elaboration in relation with Kreutzwald's legend, which diverges considerably from the published legend. Unfortunately there is little information as to in which situations and how often the narrative variant has been used.

The fifth line of relations (a dark grey broken line on the graph) is formed of hypothetical performances of the legend alongside the recorded variants and new editions. These lines, interrelated with each other and with the published anthology, begin to copy the already indicated lines of documented performances. Questions about the frequency of performances remain unanswered (even if the archived text corpus was larger, the infinite number of hypothetical/speculated performances would still remain), not to mention the times the legend has been read.

Once there was the time when the legend could not be read from any source. The situation changed after it was published in book and the book could be bought. Reportedly, the first edition of the anthology sold quite well, especially compared to Kalevipoeg (Annist \& Niit 1978: 359). If the hypothetical assumption about the times the legend was narrated and read was transferred to the same temporal axis, the general tendency might apply: to the subject once discussed only in oral lore, a parallel emerged in the form of the publication, and from then on the legend spread as the variant independent of the book or the variant based on the book. At some point, the number of oral performances started to fall: first the elements independent of the book became secondary (although they did not disappear entirely), whereas the published vari- 
ant was read and retold or passed on, but the number of times the legend was read decreased. The next new edition stirred the reading and in some cases also the retelling of the legend: there are exponentially more signs of the legend being in active use.

The vertical line of relations - the study by August Annist - takes a retrospective look at the texts emerged so far, creates a metatext of the texts, and as an analytical source text exerts its influence on new reflections, the emergence of which depends on specific important dates (the anniversary of the author, and publication dates of the anthology) and/or scholarly interest.

\section{THE LANDSCAPE WITH A SHINBONE: BEFORE AND NOW}

Bakhtin's principle of "double-grounding" in a literary work (novel) has been regarded as working not only for a novel but for any object of interpretation, including also folktales (Hufford 2003: 147-148). The two "events" that the readers have before them are "the event that is narrated in the work and the event of narration itself (we ourselves participate in the latter as listeners or readers), these events take place in different times (which are marked by different durations as well) and in different places but at the same time these two events are indissolubly united in a single but complex event that we might call the work in the totality of all its events, including the external material givenness of the work, and its text, and the world represented in the text, and the author-creator and the listener or reader" (Bakhtin 2002: 255). In the legend, the aspects of actual perceptions of time and space and narrating of temporal and spatial experience get interrelated. How can they be observed in the legend under discussion?

References to the peculiarities of the landscape of Neeruti have been made in biographical articles on Kreutzwald (see Suits 1984: 13); in the articles the spatial settings of legends about Kalevipoeg are pointed out, and detailed descriptions emphasising the local identity of the nature of the area:

Forests cover the high ridges of eskers, shaped like unopened pea pods placed edgeways, which slopes, sometimes up to thirty metres high, may tilt up to 45 degrees. In addition there are flatter eskers which look like a Pullman loafs of bread, drumlins shaped like Vienna bread, and kames shaped like buns. The relief forms at Neeruti are aptly called Kalevipoeg's furrows, as people believe in Neeruti that our epic hero ploughed land there. The long esker ridges running in parallel lines leave the impression as if somebody had made farrows with a gigantic plough. Instead, 
the landscape has been shaped by the vast glacier sheet which covered the area in Ice Age (Kruusi 2002: 23-24).

This landscape also comprises the spatial setting of the legend of "The Whining Shinbone". Localised lore is categorised in two depending on whether the told event or situation left some mark on the landscape - a perceivable natural object - or not; or whether the natural object underwent considerable changes compared to its previous state. The stones cast by legendary character Kalevipoeg and the furrows he ploughed may be constantly observed (unless the landscape has been changed). In other tales the legend events are localised on the landscape but no perceivable mark of the event or the situation is left, and there are no easily traceable landmarks to point to the locale of the legend.

As the variant examples (with a few exceptions) indicate, the locale of the whining shinbone was defined but not oriented at a specific natural object. Identifying a single lower pit in the area of numerous valleys is not an easy task. The landscape at Aruküla is visually highly enjoyable, and is enriched by the legends connected with Kalevipoeg. This visual image was complemented by a rather marginal legend relating to an auditive experience - the locals often heard a howling noise at nights. Kivi who recorded the legend referred to the noise as "growling". According to the personal letter by Kreutzwald, the

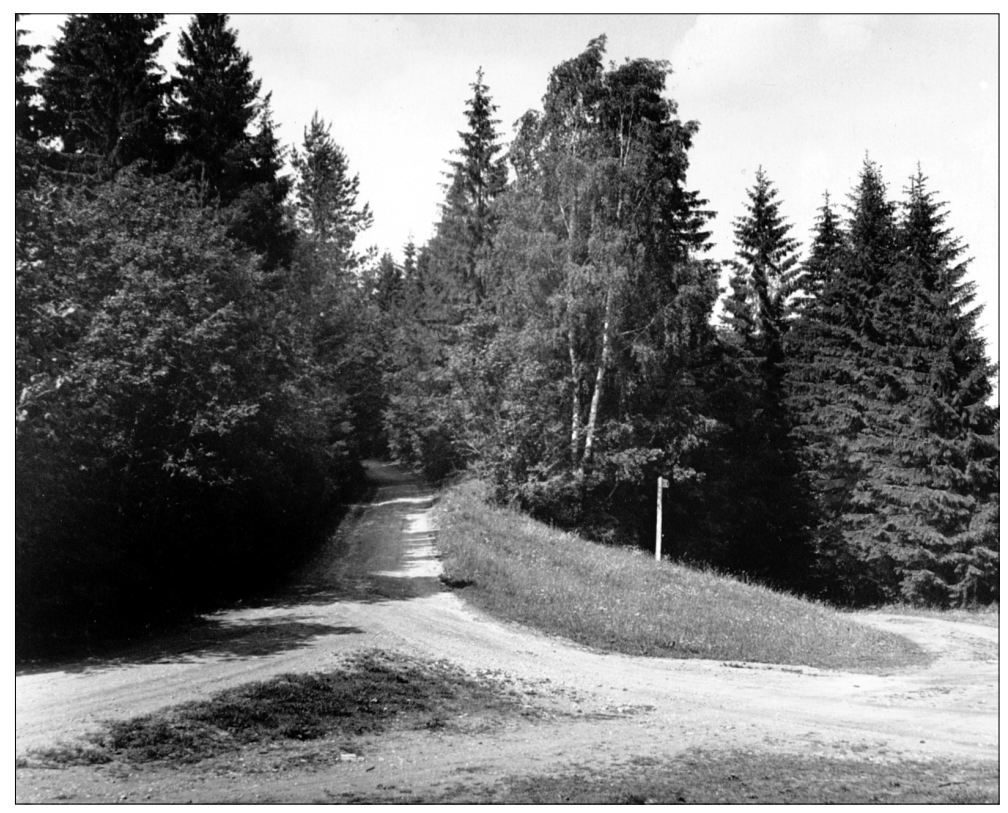

Figure 3. Landscape in Neeruti. A view of the ridge of "Kalevipoeg's furrow" in Neeruti from Sadulamäe hill. The branch of the road on the right descends towards Neetauk. Photo by Richard Hansen (1965). Photo collection of Estonian Folklore Archives. 
bone howled every night; in the variant by Hannov, which in other aspects bears a considerable resemblance to the published legend in spite of their being set in a different locale, the traveller hears a call for help; Nõlvandi imitated in her narration (see Variant 6) the sound that every passerby could hear. A human body was left unburied in the course of war; the situation was projected in the narrative, and the bone kept reminding people of its existence until the unfair situation found its solution. The soul found peace and the landscape grew silent.

Is there any point in trying to determine the location of the legend? There is no sign of it on the landscape; the noise described in the legend can no longer be heard because the cause of the howling was identified and the problem solved in the event described in the legend.

In the following section, the issue of place descriptions in legend variants will be discussed.

Kreutzwald 1862: "Somewhere in a pit near Aruküla village" (in Jõepere, Kadrina parish, not far from the town of Rakvere).

Kreutzwald's published legend since 1866: “The road passes a narrow valley on the way from Aruküla village in Jõepere towards the Kadrina church";

Hannov (1888): in amidst a field in Laius-Tähkvere;

Kivi (1897): "was heard on the church way from the distant forest, but where exactly, it does not say."

Treumann (1902): "Säärevere is located in Neeruti, Kadrina parish. There is a hill called Ämmamägi. This is where the shinbone was lying";

Metson (1930): "There on the ground, where the young Swedish emperor was buried in Aruküla village";

Nõlvandi (1984): where people went from Jõepere to Aruküla village;

The tourist website (2005): points to the published legend, but provides a different and far more accurate location than described by the published legend: "There is a round valley connected with the same legend, called the Säärevere hole near the Aruküla village."

Local landmarks are most commonly used in the legend "The Whining Shinbone" (except for the text contributed by Kivi, which remains unlocalised. The recorded variants of the legend aspire to be recordings of oral narrative lore connected with a specific locale, people and landscape. The aim has not been to create a monumental generalising text, but to allocate a specific legend a corner of the landscape otherwise enriched with legends of Kalevipoeg. In this aspect the few intermediary dissonances in textualisation like the introducing of the motif of the bone's transformation into a human or the extremely la- 
conic formulation in the text (Variant 5) recorded in 1930 (partly owing to the lack of a recording device), or even the stylistic elaborations by Kreutzwald and after him Hannov do not alter the physical or the legendary landscape.

The legend of "The Whining Shinbone" maintains its touch with the locality also because the legend is not circulated far from the claimed locale. The archive texts that draw on the legend by Kreutzwald have been recorded in the Viru County or Northern Tartu region. Unlike the legend about the origin of the Oleviste church (see Kreutzwald 1847) or the tale of the old man waiting for Tallinn to be finished, which have been recorded as oral lore or written down from printed texts in different parts of Estonia, the lore piece which is set in the Aruküla village has not migrated.

It would be unfair to leave out certain facts which offer a different view to Kreutzwald's legends and their later variants. These concern the way in which Kreutzwald structured different episodes to create the tales. According to Annist, Kreutzwald imported to this legend a West-Estonian tale of a dead king, and a well known treasure-finding tale in which the villager who came upon a great fortune left his home place (Annist 1966: 236-238). Since the local tale about howling in the vicinity of Aruküla was known in Kadrina parish, and this was also known to Kreutzwald, there was no need to necessarily relocate a legend from another part of Estonia in order to create a "proper" legend. The tale plot about a siege to a town in a war of distant past was told mostly about Haapsalu, but Kreutzwald incorporated the plot into the legend about the Lord of Palmse who saved Tallinn from the enemy (Ein Herr von Pahlen rettet Reval aus Feindeshand; Kreutzwald 1881: 174-175). It has not been established who determined that the legend about drowning the sister, which was originally connected with Rannu and Lake Võrtsjärv, was localised on Lake Porkuni (on discussion, see Annist 1966: 232; on the chronicle background and historical characters of the tale about drowning the sister, see Dehn 1886: 66-90). Narrative repertoire certainly includes numerous examples about the localisation of international migratory motifs but these motifs do not localise on their own. On rare occasions, it is possible to point out who determines the setting of a legend. It cannot be ruled out that it was Kreutzwald who choose the place "somewhere in the bottom of the valley near Aruküla village" (Variant 1), and following the line of relations independent of the first variant based on the published anthology or the fourth variant which has not been influenced by the anthology the locality of the legend was changed in the course of its circulation. 


\section{CONCLUSION}

All the place descriptions (and places mentioned) in the variants of the legend of "The Whining Shinbone" are reality-based. Events in legends containing the motif of the howling shinbone have not brought about a noticeable change on the landscape, in which one site or another have come to be associated with the legend. Therefore, the narrators and recorders of the legend have had the freedom of choice but also responsibility to position the locality of the setting and to structure other episodes. The application of narrator's freedom and responsibility in constructing the story varies in different instances of textualisation.

While constructing the legend of "The Whining Shinbone", Kreutzwald acted as the performer of a piece of narrative lore who structured the episodes known to him into a performance he considered acceptable in the narrative context. The "voice" of the published legend was strong enough; it was intensified often enough, and it was influential enough to inspire new variants of the same legend, which sometimes have been influenced by printed texts. Alternative voices, however, may exist.

As the variant recorded in 1984 indicates the retelling which was borrowed from a legend anthology and which entered the circulation at one point in time may sound remarkably folkloric and brilliant as a tale, regardless of the fact that the original Kreutzwald's style has been completely eliminated and the legend - though still set in the same locality - has been completely repositioned in time. The detailed and brilliant storytelling of Linda Nõlvandi was utterly acceptable as such in the context of the second half of the 20th century. In the last decades of the 19th century, the reader of Eesti rahva ennemuistsed jutud was also generally content with the legends: the favourable reception of the legend by readers at the end of the 19th century is suggested by folklore collector and tailor Hans Anton Schults's emotional argument in support of the idea that the legends were popular among Estonians (in Folklore Archives H II 67, 466/7 < Koeru parish 1893). The favourable reception of legends at the turn of the 20th and 21st century is evidenced by the fact that the 1996 reprint of Eesti rahva ennemuistsed jutud and Paiklikud ennemuistsed jutud published in 2003 are all sold out by 2005 .

The study of legends written down from oral tradition and the bibliographic analysis of printed anthologies suggest that their reciprocal influence in the culture is continuing. The legends published first in the 19th century by Kreutzwald, among them also "The Whining Shinbone" legend, are repeatedly reactivated in culture, continuing the conditional chain of intertextual relations. 
Motives for reviving legends may at first prove difficult to recognize but they can be found in the need to retell about the locations that are important for the readers, and therefore represent the vitality of cultural souce texts.

\section{Translated by Kait Tamm}

\section{COMMENTS}

1 See, for example, Talvet 2003, Jaago 2005: 19-23. Information about the life and activities of Kreutzwald has been repeatedly included in biographies and studies in the Estonian language (for bibliographical data until the second half of the 1960s, see Laidvee 1969).

2 The impact and allusions of Kalevipoeg in Estonian culture and in ohter countries have been studied as a model of intertextual relations in the framework of CULTOS, the joint project of literary theory and information technology (see Laak \& Viires 2004). In their study, Marin Laak and Piret Viires point out the main characteristic features and interpretations of the epic.

${ }^{3}$ On Kreutzwald as a scholar of folklore, see Jaago 2005.

4 The German translation of the collection, however, does not include the same comment on the title page and has a laconic Estnische Märchen Ausgezeichnet von Friedrich Kreutzwald (Kreutzwald 1881) instead.

5 Depending on the method of analysis, this situation may be seen as something more than a minor textual conflict and may represent, for example, the clash in principles of communication, fighting for the right and way how to publish the folklore of ethnic people - in other words, the conflict of ideas.

${ }^{6}$ In most studies on Kreutzwald's anthology, Localsagen have been fairly - in some cases completely - neglected. An exception here is the extensive study by August Annist, the Estonian folklorist and literary theorist, on the sources and poetics of Kreutzwald's Märchen (1966), although his study also focuses on Märchen, as indicated in the title.

7 Further on the subject on the example of Estonian folk tales see Vahtramäe 2003; Toomeos-Orglaan 2003; on recent studies by Finnish scholars see for example Satu Apo (2007).

${ }^{8}$ Kreutzwald was highly interested in publishing the German translation, which proved too difficult. His efforts were finally rewarded, though, and two volumes of the Estnische Märchen was published in German. The first volume, containing only Märchen, was published in 1869 in Halle, Germany, and the volume containing both Märchen and 18 Localsagen was published in Tartu (see Kreutzwald 1881).

${ }^{9}$ Cf. Jeff Todd Titon: "Folklorists understood intertextuality through versions and variants and genres of the folklore texts long before literary critics began to see it as a feature of all texts“ (2003: 74). 
${ }^{10}$ As to Localsagen, textbooks of Estonian literature contain, for example, Miks Tallinn iial valmis ei tohi saada? ('Why Can't Tallinn Ever Be Finished?', which has appeared in school readers since 1875). In the second half of the 20th century, the legend was known by its drama version Ülemiste vanake ('The Old Man of Lake Ülemiste') by the famous Estonian author and playwright Oskar Luts.

11 The titles of legends from the collection by Kreutzwald.

${ }^{12}$ Anton Schiefner (1917-1879), a linguist, ethnologican and orientalist of Balto-Finnic origin, academician of the St Petersburg Academy of Sciences (1852).

${ }^{13}$ Kreutzwald's correspondence also include other variants of Localsagen, whereas these diverge from those published in the anthology considerably. E.g. Kreutzwald's letter to Alexander Heinrich Neus from January 6, 1848 contains the legend of Lake Emujärv and Lake Virtsjärv (cf. printed publications Emmujärw und Wirtsjärw; Kreutzwald 1881: 165-167 and Kreutzwald 1956: 55-56; the German original of the letter held in the Estonian Cultural History Archives, F 24, M 63: 1)

${ }^{14}$ Some passages of the example text have been omitted. Interpunctuation marks brief stops or longer pauses in the speech flow.

${ }^{15}$ Today, the local people prefer to call the village by the name of Pariisi. The origin and development of the toponym have inspired a corresponding legend (see Loik 1975; Leppik 1997: 34).

${ }^{16}$ I would not overemphasise one feature of intertextuality - namely, the recognisability of the source text in the new text (see for example Laitinen 1995: 144). There are always some who recognise the source text while reading (or hearing) and others who consider the text as a new text. In some instances, an intermediary link is recognised instead of the beginning of an intertextual chain, and this intermediary link is then perceived as the source text of the given text (further see Pekka Tammi's introduction 1991). The same can be observed in the fate of the legend of "The Whining Shinbone" as a narrative. Nõlvandi, the informant, mentioned the name of the person who told her the tale; Treumann emphasised Kreutzwald's anthology, while Kivi's informant chooses not to disclose this information.

${ }^{17}$ According to this model, the epic, as a source text, is located in the narrow passage of the hourglass. The lower bulb contains the source texts (folk songs, mythological icons, folktales, and the epics of other nations) of the source text of the epic Kalevipoeg. The upper bulb of the hourglass contains the target texts (e.g., modern Estonian literature, arts, music, film, commercials, comic strips, etc.) which are intertextually connected with the source text and mediated through different channels. The same model cannot be applied to demonstrate the intertextual relations in the legend "The Whining Shinbone". The model is applicable to some other types of Localsagen, definitely in the cultural analysis of the influences of legends The Mistress of Porkuni (Das Fräulein von Borkholm; see Kreutzwald 1881: 154-155) and Why Can't Tallinn Ever Be Finished (Warum Reval niemals fertig werden darf; see Kreutzwald 1881: 152-153). 


\section{REFERENCES}

Aarne, Antti 1918. Estnische Märchen- und Sagenvarianten: Verzeichnis der zu den Hurtschen Handschriftsammlungen gehörenden Aufzeichnungen. Folklore Fellows Communications 25. Helsinki: Suomalainen Tiedeakatemia.

Annist, August 1966. Friedrich Reinhold Kreutzwaldi muinasjuttude algupära ja kunstiline laad. [The Origin and Style of Folk Tales by Friedrich Reinhold Kreutzwald.] Tallinn: Eesti Raamat.

Annist, August 1987. Fr. R. Kreutzwald kui teadlane ja publitsist. [Kreutzwald As a Scholar and Publisher.] In: A. Annist \& H. Puhvel (eds.) Elu ja luule: Artikleid ja mälestusi. Tallinn: Eesti Raamat, pp. 127-167.

Annist, August 2005. Friedrich Reinhold Kreutzwaldi "Kalevipoeg". [Kalevipoeg by Friedrich Reinhold Kreutzwald.] Tallinn : Eesti Keele Sihtasutus.

Annist, August \& Niit, Heldur 1978. Järelsõna. Eesti rahva ennemuistsed jutud. Rahva suust korjanud ja üles kirjutanud Friedrich Reinhold Kreutzwald. [Afterword. Estonian Folk Tales. Written and recorded from the people of Estonia by Friedrich Reinhold Kreutzwald.] Tallinn: Eesti Raamat, pp. 354-368.

Apo, Satu \& Hackston, David 2007. The Relationship between Oral and Literary Tradition as a Challenge in Fairy-Tale Research: The Case of Finnish Folktales. In: R. B. Bottigheimer Marvels \& Tales. Fairy Tales, Printed Texts, and Oral Tellings. Vol. 21, No. 1, pp. 19-33.

Bakhtin, Mikhail 1987. Valitud töid. [Selected Works.] Tallinn: Eesti Raamat.

Bakhtin, Mikhail 1996. Проблема текста. Бочаров, С.Г. \& Гоготишвили, Л.А. Problema teksta. In: S. G. Bocharov \& L. A. Gogotishvili (eds.) М. М. Бахтин. Собрание сочинений т. 5. Работы 1940-х-начала 1960-х годов. Москва: “Русские словари", M. M. Bakhtin. Sobranie sochinenii t. 5. Raboty 1940-kh-nachala 1960-kh godov. Moskva: "Russkie slovari" pp. 306-326; 618-647.

Bakhtin, Mikhail 2002 [1975]. Forms of Time and of the Chronotope in the Novel. In: M. Holquist (ed). The Dialogic Imagination. Four Essays by M. M. Bakhtin. Slavic Series 1 (I). Austin: University of Texas Press, pp. 84-258.

Bauman, Richard 2004. A World of Others' Words. Cross-Cultural Perspectives on Intertextuality. Blackwell Publishing.

Bienemann, Friedrich jun. 1897. Livländisches Sagenbuch. Reval: Verlag von Franz Kluge.

Dehn, August von 1886. Ueber die historischen Personen des Pantenius'schen Romans "Die von Kelles". Sitzungsberichte der gelehrten estnischen Gesellschaft zu Dorpat 1885. Dorpat: Gelehrte Estnische Gesellschaft, pp. 48-90.

www.eestigiid.ee Available at http://eestigiid.ee/?CatID=94\&ItemID=1397, last accessed on April 27, 2005.

Ellis, Bill 1989. When is Legend? An Essay in Legend Morphology. In: G. Bennett \& P. Smith (eds.) The Questing Beast. Perspectives on Contemporary Legend 4. Sheffield: Sheffield Academic Press, pp. 31-53.

Honko, Lauri 2000. Thick Corpus and Organic Variation: An Introduction. In: L. Honko. (ed.) Thick Corpus, Organic Variation and Textuality in Oral Tradition. Studia Fennica. Folkloristica 7. Helsinki: Finnish Literature Society, pp. 3-28. 
Hufford, Mary 2003. Context. In: B. Feintuch (ed.) Eight Words for the Study of Expressive Culture. Urbana \& Chicago: University of Illinois Press, pp. 146-175.

Jaago, Tiiu 2005. Friedrich Reinhold Kreutzwald and the Cultural Bridge. Kuutma, Kristin \& Jaago, Tiiu (ed.) Studies in Estonian Folkloristics and Ethnology. A Reader and Reflexive History. Tartu: Tartu University Press, pp. 19-36.

K[reutzwald], F[riedrich Reinhold] 1847. Wie Ollew die Kirche in Reval baute. Inland, Nr. 45, vg 1061-1064.

Kreutzwald, Fr[iedrich Reinhold] 1850. Der dankbare Fürstensohn. Estnisches Volksmährchen. Vorerinnerung. Verhandlungen der gelehrten Estnischen Gesellschaft zu Dorpat. Zweiter Band. Drittes Heft. Dorpat, pp. 74-76.

Kreutzwald, Friedrich Reinhold 1866. Eestirahva ennemuistesed jutud. Rahva suust korjanud ja üleskirjutanud Fr. R. Kreutzwald. Suomalaisen Kirjallisuuden Seuran Toimituksia 42. Helsinki: [Finnish Literary Society].

Kreutzwald, Friedrich 1881. Estnische Märchen. Aus dem Estnischen übersetzt von F. Löwe. Zweite Hälfte. Dorpat: Verlag von C. Mattiesen.

Kreutzwald, Friedrich Reinhold 1953. Personal correspondence between Fr. R. Kreutzwald and A. Schiefner from 1853-1879. In: E. Jannsen, M. Lepik et al. (eds.) Fr. R. Kreutzwald's correspondence, Vol. 3. Tallinn: Eesti Riiklik Kirjastus.

Kreutzwald, Friedrich Reinhold 1956. Kirjad A. H. Neusile, E. Sachssendahlile ja teistele 1847-1866. [Letters to A. H. Neus, E. Sachssendahl and Others 1847-1866.] In: E. Ertis et al. (eds.) Fr. R. Kreutzwald's correspondence, Vol. 2. Tallinn: Eesti Riiklik Kirjastus.

Kreutzwald, Friedrich Reinhold 1959. Kirjad G. Schultz-Bertramile ja teistele 1859-1874. [Letters to G. Schultz-Bertram and Others 1859-1874] In: M. Lepik (ed.) Fr. R. Kreutzwald's correspondence, Vol. 4. Tallinn: Eesti Riiklik Kirjastus.

Kreutzwald, Friedrich Reinhold 2003. Paiklikud ennemuistsed jutud. [Local Folk Tales.] Tallinn: Varrak.

Kristeva, Julia 1980. Desire in Language: A Semiotic Approach to Literature and Art. New York: Columbia University Press.

Kruusi, Heiko 2002. Kalevipoja künnivaod viivad Pariisi. [Kalevipoeg's Furrows Lead to Pariisi.] Loodus, Vol. 1 (February), pp. 22-26.

Laak, Marin 2003. Monument vs alustekst: "Kalevipoja" retseptsioonist ja intertekstuaalsusest. [Monument versus Source Text: On Reception and Intertextuality of Kalevipoeg.] In: K. Kuutma (ed.) Paar sammukest: Eesti Kirjandusmuuseumi aastaraamat, 20. Tartu: Eesti Kirjandusmuuseum, pp. 129-142.

Laak, Marin \& Viires, Piret 2004. Intertextuality and Technology: The Models of Kalevipoeg. In: M. Grishakova \& M. Lehtimäki (eds.) Intertextuality and Intersemiosis. Tartu: Tartu University Press, pp. 287-312.

Laidvee, Herbert 1969. Fr. R. Kreutzwaldi bibliograafia. [Bibliography of F. R. Kreutzwald.] Tallinn: Eesti Raamat.

Laitinen, Kai 1995. Aino Kallaksen mestarivuodet. Tutkimus hänen tuotantonsa päälinjoista ja taustasta 1922-1956. Helsinki: Otava.

Leppik, Eduard 1997. Neeruti maastikukaitseala juht. Kadrina mapp. Kohtla-Järve [Guide to Neeruti Nature Protection Area. Kadrina Files. Kohtla-Järve.]: E. Leppik.

Loik, Enn 1975. Neeruti lood. [Legends of Neeruti.] Punane Täht, pp. 90-100. 
Makkonen, Anna 1991. Onko intertekstuaalisuudella mitään rajaa? In: A. Viikari (ed.) Intertekstuaalisuus. Suuntia ja sovelluksia. Tietolipas 121. Helsinki: Suomalaisen Kirjallisuuden Seura, pp. 9-30.

Suits, Gustav 1984. Noor Kreutzwald: [monograafia][Monograph: Young Kreutzwald]. Loomingu Raamatukogu, Vol. 1/2 (1361/1362). Tallinn: Perioodika.

Talvet, Jüri 2003. Kalevipoeg. A Great European Epic. Estonian Literary Magazine 17 (Autumn): pp. 4-9. Available online at www.einst.ee/literary/autumn2003/, last accessed in November 2008.

Titon, Jeff Todd 2003. Text. In: B. Feintuch (ed.) Eight Words for the Study of Expressive Culture. Urbana \& Chicago: University of Illinois Press, pp. 69-98.

Tohver, Liis 1932. Kreutzwaldi väliskirjanduslikust eruditsioonist. Mit einem deutschen Referat: Kreutzwalds Belesenheit in den fremden Literaturen. Akadeemilise Kirjandusühingu toimetised. VIII. Tartu: Akadeemiline Kirjandusühingu Kirjastus.

Toomeos-Orglaan, Kärri 2003. “Kinder- und Hausmärchen” eesti imemuinasjuttude allikana. [Kinder- und Hausmärchen as the Source of Estonian Fairy Tales.] In: M. Hiiemäe \& K. Labi (eds). Teekond. Pro Folkloristica X. Tartu: Eesti Kirjandusmuuseum, pp. 183-196.

Valk, Ülo 2002. Authorship and Textuality. The Kalevipoeg as Epic Landscape. In: L. Honko (ed.) The Kalevala and the World's Traditional Epics. Studia Fennica Folkloristica 12. Helsinki-Tampere: SKS, pp. 407-419.

Vahtramäe, Ell 2003. Rahvajutud ja raamatujutud. Suulise ja kirjaliku kultuuri lõikumiskoht kui väljakutse folkloristikale. [Folk Tales and Book Tales. Intersection of Oral and Written Culture as a Challenge in Folklore Studies.] In: T. Jaago (ed.) Pärimus ja tõlgendus: Artikleid folkloristika ja etnoloogia teooria, meetodite ning uurimispraktika alalt. Tartu: Tartu Ülikooli Kirjastus, pp. 104-116. 